\title{
Gender and Socioeconomic Factors Influencing Domestication of Medicinal Plants in North West of Ethiopia
}

\author{
Dereje Mosissa \\ Ethiopian Biodiversity Institute Assosa Biodiversity Center
}

\begin{abstract}
This paper examines the influence of gender and socio-economic factors on domestication of medicinal plants in Assosa Zone of Western Ethiopia. Participatory wealth ranking, structured and semi-structured interviews, botanical surveys and participant observations were the main methods employed in data collection. The results showed that the domestication has played a fundamental role in conserving medicinal plants in the study area. Forty (89 percent) and 12(27 percent) out of 45 indigenous plant species were domesticated on farms and around homesteads, respectively. About 89 percent of the respondents $(n=173)$ had domesticated medicinal plants on their farms and around homesteads. Gender featured as important factor that had influence on this practice, with male-headed households shown to outdo the female-headed households in the domestication effort. This can be attributed to social and cultural reasons that besides dispossessing women of the tenure rights over resources and land, they also subject them to heavy workloads and, therefore, diminish the time required for domestication. The number of domesticated medicinal plants also depended on age, affluence, farm size, household size and ethnicity. In conclusion, the paper urges that since domestication - an important strategy for conserving threatened medicinal plants in farmlands and around homesteads - is being influenced by gender and socioeconomic factors, agroforestry research should focus, not only on integrating forest plants in farmlands, but also on socio-cultural, socio-economic and institutional aspects affecting the whole system of domestication.
\end{abstract}

Keywords: biodiversity conservation, cultural values, medicinal plants, livelihoods.

DOI: $10.7176 /$ ALST/76-01

Publication date:September $30^{\text {th }} 2019$

\section{INTRODUCTION}

The potential role of medicinal plants

Medicinal plants are essential components of primary health care, especially for the rural communities, who by geographical and economic reasons cannot access the modern western medical services. Literature has cited World Health Organization (WHO) estimating world population relying on traditional medicines for their primary health care to be four billion people, $80 \%$ of them coming from developing countries (Augustino and Gillah 2005; Schippmann et al 2006). The high reliance on traditional medicines is mainly caused by a low ratio of the university trained doctor to rural populations. For example, the ratios of traditional healers and that of medical doctors to patients in Ethiopia were 1:1100 and 1: 33,000 1:708 and 1:25,000 (World Bank 1993); Malawi - 1:138 and 1:50,000 (Msonthi and Seyani 1986) and; Mozambique - 1:200 and 1:50,000 (Green 1994). The population growth and worsening economic situation is exacerbating this imbalance and there is no hope to reverse this trend in the near future (Ishengoma and Gillah 2002; Augustino and Gillah 2005). In Ethiopia, for example, the ratio of doctors to patients had decreased from 1:33,000 in 1993 to 1:17,000 in 2016 [Abdallah et al 2007].

Prominence of traditional medicines, manifested by a high imbalance ratio between traditional healers and modern medical doctors, are caused by - among other factors - inadequate medical facilities, poor accessibility to western medical services, low purchasing power among the rural people and the trust that people have over the efficacy of medicinal plants (Green 1994; Thomas 2002; Hamilton 2003; Abdallah et al. 2007). The reality that the world is experiencing an increasing rate of resistance by pathogens to some of the synthetic drugs and that some of the diseases such as cancer, diabetes and AIDS have not found treatments from modern medicine has also increased the popularity of the traditional medicines (Msuya, 1998; Otieno, 2000; Augustino and Gillah 2005; Msuya and Kideghesho 2009). The western health care system has been criticized for divorcing treatment from the patient's culture; failure to tell the patients the nature and cause of their illness; tendency of removing the patients from the family and community, stripping of their identity and forcing them into a sterile hospital setting and; tendency of the treatment to address patient's biological manifestation of the illness rather than healing the spiritual aspects of the illness (Lashari 1984; LeBeau 1998).

Medicinal plants are popular, not only locally but also globally. Statistics indicate that between 1991 and 1998 the 12 leading countries of import of medicinal plants material paid over US\$1bn to import about 343,000 tonnes while 12 leading countries of export earned over 640 million from export of about 282,000 tonnes (Lange 2002). The top three countries of export of medicinal plants in the world were China, India and Germany which exported 139,750; 36,750 and 15,050 tonnes, respectively. The three leading countries for import with tonnes in brackets included Hong Kong (73,650), Japan (56,759) and USA 56,000 (ibid). The US National Cancer 
Institute has identified over 1,400 tropical forest plants with the potential to fight cancer (WCMC 1992.). Catharanthus roseus, native to Madagascar, is one of such plants. This species that has been used for generations by traditional healers is now an important raw material for drugs effective against Hodgkins disease and other forms of cancer (ibid.).

\section{Threats facing the medicinal plants}

The WHO (1998) estimates of the number of plant species used medicinally worldwide stood at 72,000 . This is about $17.1 \%$ of the total number of flowering plant species i.e. 422,000 (Govaerts 2001). The world trends such as market forces, population growth and high demand of these species - not only for primary health care, but also for commercial and several other purposes such as fuelwood, timber and poles - have subjected them to overexploitation. About $21 \%$ of medicinal plant species (i.e. 15,000 species) are threatened worldwide (Bramwell 2003). Furthermore, their habitats are increasingly being destroyed through land clearing for agriculture, settlements and other developments as well as accidental and deliberate fires (Millenium Ecosystem Assessment 2005; IUCN 2006; IUCN 2008).

Susceptibility of medicinal plants to excessive harvesting is a function of various biological factors such as narrow geographic distribution, habitat specificity, slow growth rates and destructive harvest for their roots, bark or the entire plant (Schippmann et al 2006). Excessive harvesting implies exploiting the species at a rate that exceeds the annual sustained yield. This leads to genetic erosion of species that are not in cultivation as exemplified by Curcuma spp. and Parkia roxburghii in East Java and Dioscorea deltoidea in the Himalayan foothills of northern India (WCMC 1992). The later is a major source of diosgenin used in the manufacture of contraceptive pills (ibid.). On the other hand, destructive harvest involves extraction of medicinal plants that involves ring debarking and root cutting and, therefore, killing of the entire plants. This is epitomized by Prunus africana in West Africa and Warbugia salutaris in Kenya (Kokwaro 1991) and South Africa (Schippmann et al 2006).

Trade is one of the leading factors threatening medicinal plants worldwide. Many species are earmarked as raw materials by over 1,000 drug manufacturing companies and in export as crude extracts (WCMC 1992). A demand for many popular and effective medicinal plant species in Europe, North America and Asia is growing between $8 \%$ and 15\% per annum (Grünwald and Büttel 1996). Iqbal, (1993) and Leaman (2002) attribute the following eight factors to the increased demand for medicinal plants and herbal remedies in the developed countries: increasing costs of institutional, pharmaceutical-based health care; interest of individuals, communities and national governments in greater self-reliance in health care; interest of communities and national governments in small-and large-scale industrial development based on local/national biodiversity resources; increasing success in validating the safety and efficacy of herbal remedies; legislation improving the status of herbal medicine industry; renewed interest of companies in isolating useful compounds from plants; search for new drugs and treatments of serious and drug-resistant diseases and; marketing strategies by the companies dealing in herbal medicine.

The impact of increased international demand for medicinal plants has increasingly been acknowledged in literature. For example, loss of valuable plant genetic resources in some countries of Asia has been documented following overexploitation of medicinal plants such as Curcuma spp., Voacanga gradifolia, Orthosiphon aristasus, and Rauvolfia serpentine (WCMC 1992). In Tanzania about nine medicinal plants that were reported to be traded locally and internationally were identified by the Wildlife Trade Monitoring Network (TRAFFIC) as the most in need of conservation, management and research due to their endangered status caused by excessive harvesting. These species were: Dioscorea dumetorum, Cadaba farinosa, Milicia excelsa, Acalypha fructicosa, Harrisonia abyssinica, Steganotaenia araliacea, Acacia melifera, Ehretia amoena, and Wedelia mossambicensis [Marshal 1998]. Similar impact of trade is reported for Prunus africana in West Africa and Madagascar, Warbugia salutaris in South Africa and Saussurea costus in the Himalayas (Schippmann et al 2006). Threat of extinction prompted addition of the following 17 medicinal plants into CITES (Convention on International Trade of Endangered Species of Wild Fauna and Flora) Appendices: Adonis vernalis, Aquilaria malaccensis, Cistanche deserticola, Dioscorea deltoidea, Guaiacum officinale, Guaiacum sanctum, Hydrastis Canadensis, Nardostachys grandiflora, Panax ginseng, Panax quinquefolius, Picrorhiza kurroo, Podophyllum hexandrum, Prunus Africana, Pterocarpus santalinus, Rauvolfia serpentine, Saussurea costus and Taxus wallichiana (Schippmann et al 2006). It is because of the threats facing medicinal plants, that the Medicinal Plant Specialist Group was founded in 1994, under the auspices of the Species Survival Commission of the IUCN - the World Conservation Union-to increase global awareness of conservation threats to medicinal plants and to promote conservation actions. One of such actions is domestication.

\section{Domestication of medicinal plants}

Domestication has been defined as an indigenous agroforestry practice that involves retaining plant species of forest origin in the farms during the process of clearing land for cultivation and/or bringing forest plants to the 
farms or homesteads for the purpose of reducing the exploitation pressure of wild stocks (Shepherd 1992; Wiersum 1997; Kessy and Temu 2000). The practice is regarded as one of the conservation options that can relieve a pressure for medicinal species which are most susceptible to threat of extinction due to rarity and slowgrowth rates (WCMC 1992; Augustino and Gillah 2005; Uniyal et al 2000; Schippmann et al 2006; Msuya and Kideghesho 2009).

Besides relieving pressure of overexploitation, domestication of medicinal plants has other numerous advantages over wild collection. According to Schippmann et al. (2006) domestication: guarantees continuing supply of raw material; makes reliable botanical identification possible; secures steady supply of herbal medicines (home gardens); makes the quality standards easy to maintain; makes controlled post-harvest handling possible and provides in-country value-adding. Furthermore, with domestication wholesalers and pharmaceutical companies can agree on volumes and prices over time with the grower; resource price remains relatively stable over time; certification as organic production is possible and; the selection and development of genotypes with commercially desirable traits from the wild or managed populations may offer opportunities for the economic development of the medicinal plant species as a crop.

\section{Influence of gender and socioeconomic factors on domestication of medicinal plants}

Domestication of medicinal plants has been practiced in Etiopia since prehistoric times (Wiersum et al., 1985; Kajembe, 1994; Kaoneka and Solberg, 1997; Moshi, 1997, Msuya, 1998). Although it is unlikely that the situation will change in the near future, there are a number of factors affecting domestication of medicinal plants in this area, which need to be examined critically and documented for sustainable use and management purposes. The focus of this paper is gender and other socio-economic factors. Knowledge of these factors is essential as it may provide a framework for prioritization of management actions and allocation of resources available for management.

Gender, one of the important factors that can influence resource conservation, has been defined as the relations between men and women, both perceptual and material (FAO 1997). The main focus of gender issues entail women and relations with men, their roles, access to and control over resources, division of labour, interests and needs (Augustino and Gillah 2005; Kingazi et al 2008). In almost all communities worldwide, women and men have different gender-based roles, responsibilities, needs as well as local knowledge pertaining to access to and control over their environment. Women's capacities and willingness to conserve resources differ from those of men. Similarly, the way women are affected by environmental degradation and declining biodiversity resources and their coping strategies against these effects are quite different from those of men. However, there is a tendency of overlooking these aspects (Talhouk et al. 2001). Augustino and Gillah (2005:45) put it correctly by arguing that "Women are not more important than men, but they deserve special attention as their roles and needs are often overlooked." They urge that because of women's marginal economic status and special interest they have in plants, domestication should be accorded a priority to them. The reality that in rural societies, women are responsible for the health of children and spend more time in caring for the sick, prompts a meticulous analysis of the influence of gender on domestication of medicinal plants as one of the important coping strategies against decline of these resources.

Besides gender, other socio-economic factors such as age, education, wealth, ethnicity, farm and household size can influence the domestication efforts. These factors also need to be critically analysed to understand how they enhance or impede domestication of medicinal plants. This paper seeks to show how gender and socioeconomic factors can influence the domestication of medicinal plants in Western Ethiopia. It is framed around two main questions: (1) which medicinal plants are domesticated in farms and around homesteads and (2) how does gender and socio-economic factors influence domestication of medicinal plants.

\section{STUDY AREA AND METHODOLOGY}

Assosa Zone is one of the three Zones in Benishangul-Gumuz Region west of Ethiopia. Asosa Zone is bordered on the south by the Mao-Komo special woreda, on the west by Sudan, and on the northeast by the Kamashi Zone (Fig. 1). Based on the 2007 Census conducted by the Central Statistical Agency of Ethiopia (CSA), this Zone has a total population of 310,822 , of whom 158,932 are men and 151,890 women. 39,957 or $87.14 \%$ of population are rural inhabitants. The four largest ethnic groups reported in the Asosa Zone were the Berta (59.95\%), the Amhara (23.86\%), the Oromo (10.31\%), and the Tigraways (1.5\%), 1.48\% of the population was from Sudan; all other ethnic groups made up $2.9 \%$ of the population. Main languages are the Rutana/Berta (59.31\%), Amharic (25.7\%), Oromo (10.68\%), and Tigrigna (1.07\%). The majority of the inhabitants were Muslim, with $74.08 \%$ of the population reporting that they held that belief, while $16.51 \%$ practiced Ethiopian Orthodox Christianity, and $8.57 \%$ were Protestant (CSA, 2007).

The people of the study area which belongs to the Rutana, Amharic, Arabic and Oromiffaa speaking community are mainly subsistence farmers predominantly living in rural communities, which informed their dependence on plants for their healthcare needs. For the purpose of the survey, 190 traditional healers from 
twelve kebeles were purposively selected and visited in their homes for inventory and identification of plants cultivated in their home gardens.

The process of data collection includes identification and specimen collection of the medicinal plants cultivated in the home gardens of the local communities. Information concerning the frequency of collection, distribution, mode of propagation, conservation strategies, uses and local names of the plant were obtained from traditional healers. The resulting data was analyzed using simple percentages (frequencies) analysis using Excel 2016. The plants were scientifically identified using floras and comparison of plant specimen collected with voucher specimens at the herbarium of Ethiopian Biodiversity Institute. A semi structured questionnaire was administered by interpreting it into Amharic, Rutana/Arabic and Oromiffaa languages which was mostly understood by the local communities under the study. Informed consent of the THs was obtained to make the information public before they were interviewed. Stipends were offered in appreciation of the time spent in taking us round their homesteads and responding to our questions.

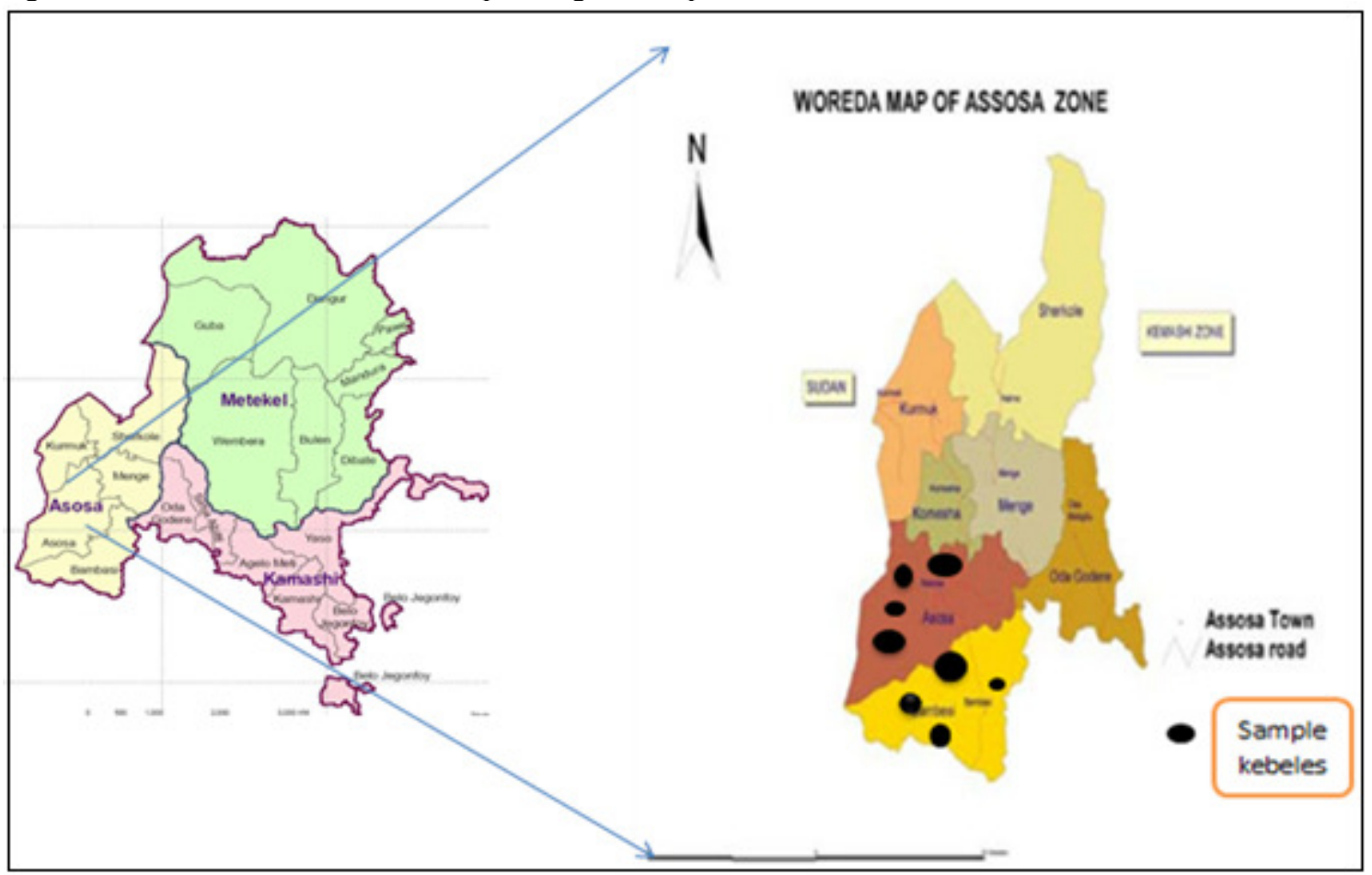

Figure 1: Map of the study area

\section{Data analysis}

Data collected in phase 1 were analysed with the help of the communities, and results were communicated back to them. The results were triangulated with data from the second and third phases. Data collected in the phases 2 and 3 were analyzed using both qualitative and quantitative methods. The qualitative data were analysed using content and functional analysis techniques (Kajembe, 1994); whereas quantitative data were analysed using Statistical Package for Social Science (SPSS) and Microsoft excel software. Regression analysis was used to establish the influence of different socio-economic parameters on domestication of medicinal plants. The general model used in regression analysis was in the form of:

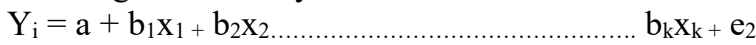

Where $\mathrm{Yi}=$ the $\mathrm{i}^{\text {th }}$ observed value of the dependent variables (i.e. domestication effort)

$\mathrm{x}_{1}$ to $\mathrm{x}_{\mathrm{k}}=$ independent variables (i.e. gender, age, family size, farm size, education, wealth and ethnicity)

$\mathrm{a}=$ intercept at $\mathrm{Y}$ axis (dependent variable)

$b_{1}$ to $b_{k}=$ regression coefficients

$\mathrm{e}=$ random disturbance error

$\mathrm{i}=1,2 \ldots \ldots \mathrm{n}$; where $\mathrm{n}$ is the total number of variables

Specifically, the hypotheses tested were:

$\mathrm{H}_{0}: ß=0$; meaning that there is no correlation between dependent and independent variables, and

$\mathrm{H}_{\mathrm{i}}: \Omega \neq 0$; meaning that there is a positive or negative relationship between dependent and independent variables 
T-test was also employed to determine the influence of gender by comparing the number of trees domesticated between male and female-headed households.

\section{RESULTS AND DISCUSSION}

\section{Domestication of medicinal plants}

Being an important practice in agroforestry, domestication has played fundamental role in conservation of medicinal plants in the study area. Forty $(89 \%)$ and $12(27 \%)$ out of 45 medicinal plant species were domesticated on farms and around homesteads, respectively (Table 1). These species treat numerous diseases as shown in Table 1.

Table 1: Domesticated medicinal plants identified in Assosa Zone, sites of domestication and diseases treated ( = species present)

\begin{tabular}{|c|c|c|c|c|}
\hline \multirow{2}{*}{ Species Name } & \multirow{2}{*}{ Family } & \multicolumn{2}{|c|}{$\begin{array}{c}\text { Sites of } \\
\text { domestication }\end{array}$} & \multirow[t]{2}{*}{ Diseases treated } \\
\hline & & $\begin{array}{c}\text { on } \\
\text { farms }\end{array}$ & $\begin{array}{c}\text { around } \\
\text { homesteads }\end{array}$ & \\
\hline Adansonia digitata & Bombacaceae & & & Stomach pains and teeth problems \\
\hline Adenia cissampeloides & Passifloraceae & & & Malaria and stomach ache \\
\hline Albizia gummifera & Mimosaceae & & & Chest pain, headache and occasional fever \\
\hline Albizia schimperiana & Mimosaceae & & & Coughs and rheumatism \\
\hline Artemisia afra & Compositae & & & $\begin{array}{l}\text { Malaria, sore throat and expulsion of } \\
\text { intestinal worms }\end{array}$ \\
\hline Basella alba & Basellaceae & & & Stomach problems especially for women \\
\hline Bridelia micrantha & Euphorbiaceae & & & Worms, diarrhoea and headache \\
\hline Catha edulis & Celastraceae & & & $\begin{array}{l}\text { Malaria, coughs, stomachache, Gonorrhea } \\
\& \text { influenza }\end{array}$ \\
\hline Clausena anisata & Rutaceae & & & $\begin{array}{l}\text { Stomach pains, worms, diarrhoea, } \\
\text { headache, malaria and influenza }\end{array}$ \\
\hline $\begin{array}{l}\text { Clerodendrum } \\
\text { myricoides }\end{array}$ & Verbenaceae & & & Venereal diseases and malaria \\
\hline Commelina latifolia & Commelinaceae & & & Eye diseases \\
\hline Commiphora eminii & Burseraceae & & & $\begin{array}{l}\text { Stomach pains, snakebite, dysentery, } \\
\text { leprosy and fever }\end{array}$ \\
\hline Cussonia arborea & Araliaceae & & & Snakebite, malaria and constipation \\
\hline Deinbollia borbonica & Sapindaceae & & & Hernia and infertility to women \\
\hline Dodonaea angustifolia & Sapindaceae & & & Toothache and intestinal worms \\
\hline $\begin{array}{l}\text { Dracaena } \\
\text { usambarensis }\end{array}$ & Agavaceae & & & Abdominal pain \\
\hline $\begin{array}{l}\text { Dracaena } \\
\text { afromontana }\end{array}$ & Agavaceae & & & Abdominal pain \\
\hline Ehretia cymosa & Boraginaceae & & & Brucellosis \\
\hline Erythrina abyssinica & Mimosaceae & & & $\begin{array}{l}\text { Malaria, convulsions for children, anthrax } \\
\text { and snakebite }\end{array}$ \\
\hline Euclea divinorum & Ebenaceae & & & Teeth ache and stomach ulcers \\
\hline Ficus sycomorus & Moracaceae & & & Diarrhoea, sore throat and chest pain \\
\hline Ficus thorningii & Moracaceae & & & Medicines to cure witched people \\
\hline Flueggea virosa & Euphorbiaceae & & & $\begin{array}{l}\text { Bilharzias, malaria, stomach-ache and } \\
\text { itching skin }\end{array}$ \\
\hline Harrisonia abyssinica & Simaroubaceae & & & $\begin{array}{l}\text { Fever, nausea, vomiting, snakebite, } \\
\text { tuberculosis, stomachache and malaria }\end{array}$ \\
\hline Grewia similes & Tiliaceae & & & Wounds, sore throat and snakebite \\
\hline Hibiscus fuscus & Malvaceae & & & Pneumonia and sore throat \\
\hline Jasticia engleriana & Acanthaceae & & & Stomach pains, coughs and colds \\
\hline \multicolumn{5}{|l|}{ Lonchocarpus capassa } \\
\hline Maesa lanceolata & Myrisinaceae & & & Diarrhoea, teeth ache and rashes \\
\hline Markamia lutea & Bignoniaceae & & & $\begin{array}{l}\text { Gonorrhoea, intestinal worms, backache } \\
\text { and fresh wounds }\end{array}$ \\
\hline
\end{tabular}




\begin{tabular}{|c|c|c|}
\hline $\begin{array}{l}\text { Microglossa } \\
\text { oblongifolia }\end{array}$ & Compositae & Stomach-ache and hernia \\
\hline Myrica salicifolia & Myricaceae & $\begin{array}{l}\text { Tuberculosis, chest pain, reduce pain for } \\
\text { cancer patients }\end{array}$ \\
\hline Newtonia buchananii & Mimosoidae & Brucellosis and inflammation of joints \\
\hline Parinari excelsa & Chrysobalanaceae & Gonorrhoea, colds and coughs \\
\hline Plectranthus barbatus & Labiatae & Malaria, teeth ache and stomach pains \\
\hline Prunus africana & Rosaceae & Hernia and neck ache, cancer \\
\hline Psidium guajava & Myrtaceae & Stomach pains \\
\hline Rauvolfia cafra & Apocynaceae & $\begin{array}{l}\text { Rheumatism, pneumonia, intestinal } \\
\text { worms and hypertension }\end{array}$ \\
\hline Senna singueana & Caesalpiniaceae & $\begin{array}{l}\text { Malaria, convulsions, epilepsy, coughs, } \\
\text { intestinal worms and constipation }\end{array}$ \\
\hline Solanum nigrum & Solanaceae & Malaria, coughs \\
\hline Syzygium guinensee & Myrtaceae & Intestinal worms and dysentery \\
\hline Tefairia pedata & Cucurbitaceae & Improve lactation after child birth \\
\hline Toddalia asiatica & Rutaceae & $\begin{array}{l}\text { Malaria, chest pain, convulsion for } \\
\text { children and infertility for women }\end{array}$ \\
\hline Trema orientalis & Ulmaceae & $\begin{array}{l}\text { Coughs, sore throat, asthma, gonorrhoea, } \\
\text { malaria, yellow fever, teeth ache and } \\
\text { intestinal worms }\end{array}$ \\
\hline Vangueria infausta & Rubiaceae & Headache, stomachache and fever \\
\hline $\begin{array}{l}\text { Zanthoxylum } \\
\text { chalybeum }\end{array}$ & Rutaceae & Stomach pains and convulsions \\
\hline
\end{tabular}

On average, each household in the study area had domesticated $5 \pm 3$ (SE) medicinal plants. The villages located far from the Forest Reserves had domesticated more medicinal plants (an average of $6 \pm 4$ (SE)) per household) compared to those situated close to forest reserves $(4 \pm 2$ (SE)). Statistically, this difference was significant $(\mathrm{P}=009, \mathrm{t}=2.62)$. Village-wise response also reflected similar situation as indicated in Figure 2 . Mender 49, Oromela and Sonka (the villages located far from the Forest Reserves) had high proportion of respondents reported to have domesticated medicinal plants compared to Basha Buda, Tsore Almetema and Gori (villages which bordered the forest reserves) (Fig. 2). This could be attributed to the fact that people from villages sharing the immediate boundaries with the forest reserves can easily meet their medicinal needs from the forests while domestication is more feasible option to those living far from the reserves.

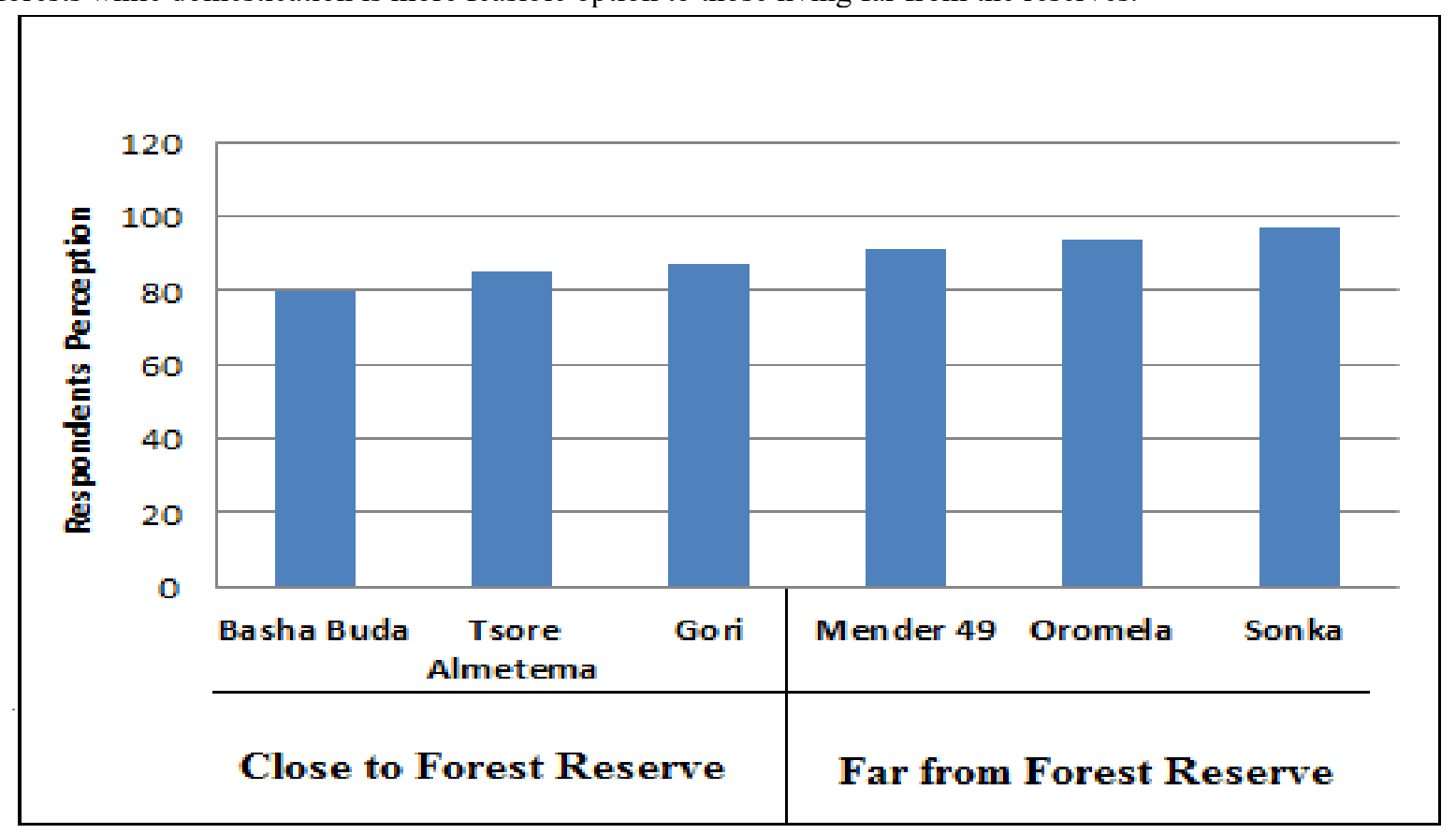

Figure 2: Response on domestication (in percentage) per village in the Western Ethiopia

As depicted by this study, majority of the respondents (89\%) reported to have practiced domestication for a long period. These results are in line with Hamilton's findings (1989) which revealed that domestication as part 
of the traditional agroforestry system and a conservation practice started in the West of Ethiopia as early as about 20 centuries ago. Similarly, domestication has been reported by various studies conducted in the study area (Kaoneka 1993; Kajembe, 1994; Moshi, 1997; Msuya, 1998; Msuya et al., 2008; Msuya and Kideghesho, in press). Certain medicinal plant species such as Albizia spp., Erythrina abyssinica, Catha edulis, and Tamarindus indica were domesticated deliberately to conserve them against excessive harvesting in their natural habitats (the forests).

Efforts of domestication of medicinal plants as a strategy of overcoming the problem of overexploitation are recognized globally. For example, in Cameroon and Madagascar, Prunus africana, which is threatened by excessive debarking for export is domesticated in areas bordering the natural forests (Cunningham and Mbenkum, 1993; Dawson, 1997). The bark of the species is used as effective medicine for ailments such as Hernia, cancer and neck ache (Msuya1998; Augustino and Gillah 2005). Quinine (Cinchona ledgeriana) used to manufacture antimalaria drugs has been developed as a major crop species in Indonesia, Tanzania, Democratic Republic of Congo, Burundi, Kenya, Guatemala, Peru, Ecuador, Bolivia, Sri Lanka, Columbia and Costa Rica (WCMC 1992). Formerly, the entire world supply came from only one source - the Andes, and thus the species was at a risk of extinction (ibid). Papaver somniferum is domesticated in Turkey, India, Burma and Thailand while Carica papaya is domesticated in Sri Lanka, Uganda, Democratic Republic of Congo, South Africa, Tanzania and India (ibid.). Through a botanical survey conducted by Kessy and Temu (2000) in 47 homegardens in the East Usambara Mountains, 18 domesticated medicinal plants were identified, one of which Cola usambarensis being endemic to the area and similar trend was observed in Assosa zone.

\section{Gender influence on domestication of medicinal plants}

From this study, it is apparent that gender had significant influence on conservation of medicinal plants through domestication. Female-headed households had domesticated more medicinal plants around homesteads than on farms while for male-headed households more domestication took place on the farms (Figure 2). Overall, maleheaded households had domesticated more medicinal plants $[6 \pm 4$ (SE)] than female-headed households $[3 \pm 4$ $(\mathrm{SE}), \mathrm{t}=3.77, \mathrm{p}=0.002]$. Study in SNNP (Kajembe et al 2008) and East Gojam (Kweka 2004) also reported similar results with more men pursuing domestication than women. Given the fact that women are more vulnerable to environmental problems and declining biodiversity, one would have expected the female-headed households to domesticate more medicinal plants than male-headed households. This, however, is not the case, the scenario that can be attributed to land tenure insecurity for women. In these mountains and elsewhere in Tanzania, land ownership is patriarch and only few widowed women could inherit land (Kaoneka, 1993; Msuya, 1998; Kweka 2004; Luoga et al. 2004). In a household, a husband makes all the decisions regarding the crops and tree species and the marketing of the products although the women shoulder over $90 \%$ of the workload. The heavy workload could also explain why female-headed households had fewer domesticated medicinal plants. In Africa, in general and in Ethiopia particularly virtually all household chores (washing, cooking, fetching water, feeding livestock, caring for children etc.) are exclusively women's responsibility (Fig. 3). Culturally, it is a shame for men to do these tasks. Women perform these household chores in addition to other economic activities such as farming. This gives women less time to invest in domesticating medicinal plants than men. 


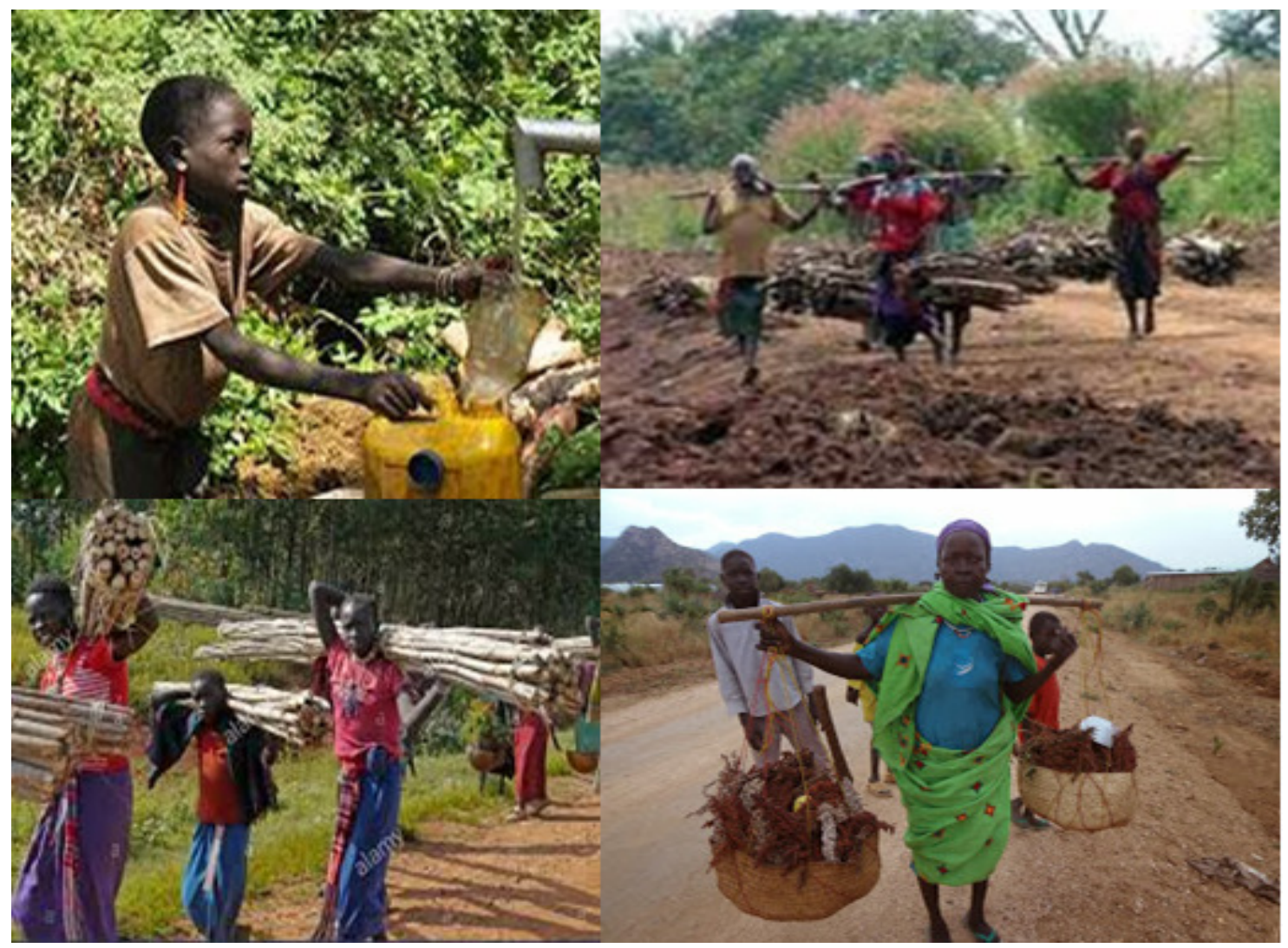

Figure 3: In Assosa Zone (Benishangul Gumuz Region) virtually all household chores are exclusively women's responsibility

Furthermore, in most cases female-headed households are economically disempowered, and therefore, they can hardly employ people to domesticate and care for medicinal plants. Elsewhere in the world, for example Thailand, domestication of indigenous forest plant species by women is not uncommon. Women were reported to have domesticated a total of 230 species for food, medicines and decorative value around homesteads (Geraldine et al., 1994).

The influence of gender on domestication of medicinal plants is not surprising. This is because the ways in which a culture or society defines the gender roles affect several aspects of life such as household security, family welfare and planning production (Bravo-Bowmann 2000). In almost all communities worldwide, women and men have different gender-based roles, responsibilities, needs as well as local knowledge pertaining to access to and control over their environment (Augustino and Gillah 2005; Kingazi 2008). Similarly, the way women are affected by environmental degradation and declining biodiversity resources and their coping strategies against these effects are quite different from those of men. Women have been recognized as both the victims of environmental degradation and a part of the solution for addressing the underlying causes of this problem (Augustino and Gillah 2005). However, as observed in this study, women's coping strategies against environmental problems are stalled by cultural and economic reasons.

\section{Influence of Socio-economic factors on domestication of medicinal plants Age}

Age of the respondents had significant effect on the number of domesticated medicinal plants in the study area (Table 2). The elders had more medicinal plants retained or planted on their farms and around homesteads than the young people $\left(\mathrm{P}=0.002, \mathrm{R}^{2}=65 \%, \mathrm{t}=3.15\right)$. This is likely to be the case since most of the elders owned bigger farms and were more familiar with medicinal plants. Similar results were reported in East Northern Ethiopia (Kweka 2004) although in Western Ethiopia, the domestication efforts were much higher for younger people than older people (Kajembe et al. 2008). The issue of knowledge as a possible reason for elders to domesticate more medicinal plants has also been reported in Kenya, where young people below 20 years knew nothing about medicinal plants unlike the elders (above 60 years old) (Quiroz 1994). There is a general consensus that the indigenous knowledge, which was previously handed down through generations by cultural transmission, is declining with age (Kideghesho 2008; Songorwa et al. 2000). The means of transmitting this knowledge, which included folklore or storytelling, continuous observations, practising and attachment on natural resources are no longer effective. Because of formal education, there is less time for recipient (youth) to 
interact with their traditional teachers (elders) and laboratory (natural resources). In Ethiopia education system, for example, nursery school begins at the age of five followed by primary school at the age of seven which lasts for seven years. Then a pupil joins secondary school and colleges for four to eight years, often in boarding schools away from the place of birth. Furthermore, the youth are more inclined to western rather than traditional medicines.

Table 2: Summary of the results of regression analysis indicating the influence of socio-economic factors (Xi) on the number of plants retained on farms and around homesteads in the Western Ethiopia

\begin{tabular}{lccc} 
& \multicolumn{3}{c}{$\mathbf{Y}$} \\
Socio-economic factors Xi & $\mathbf{R}^{\mathbf{2}}$ & $\mathbf{t}$ & $\mathbf{P}$ \\
Age & $65 \%$ & 3.15 & 0.002 \\
Wealth (assets and income) & $81 \%$ & 3.52 & 0.001 \\
Education & $26 \%$ & 0.27 & 0.21 \\
Farm size & $45 \%$ & 2.29 & 0.023 \\
Household size & $52 \%$ & 2.54 & 0.012 \\
\hline
\end{tabular}

\section{Affluence}

Wealth ranking exercise indicated that majority of the households were poor, followed by the middle class and only 5\% was ranked as rich (Fig. 4). These classes were very important in determining the domestication efforts. The number of domesticated medicinal plants was significantly influenced by affluence $\left(\mathrm{P}=0.001, \mathrm{R}^{2}=81 \%, \mathrm{t}\right.$ =3.52). Although the poor constituted the majority of households in the study area, they had domesticated fewer medicinal plants than the few wealthy households.

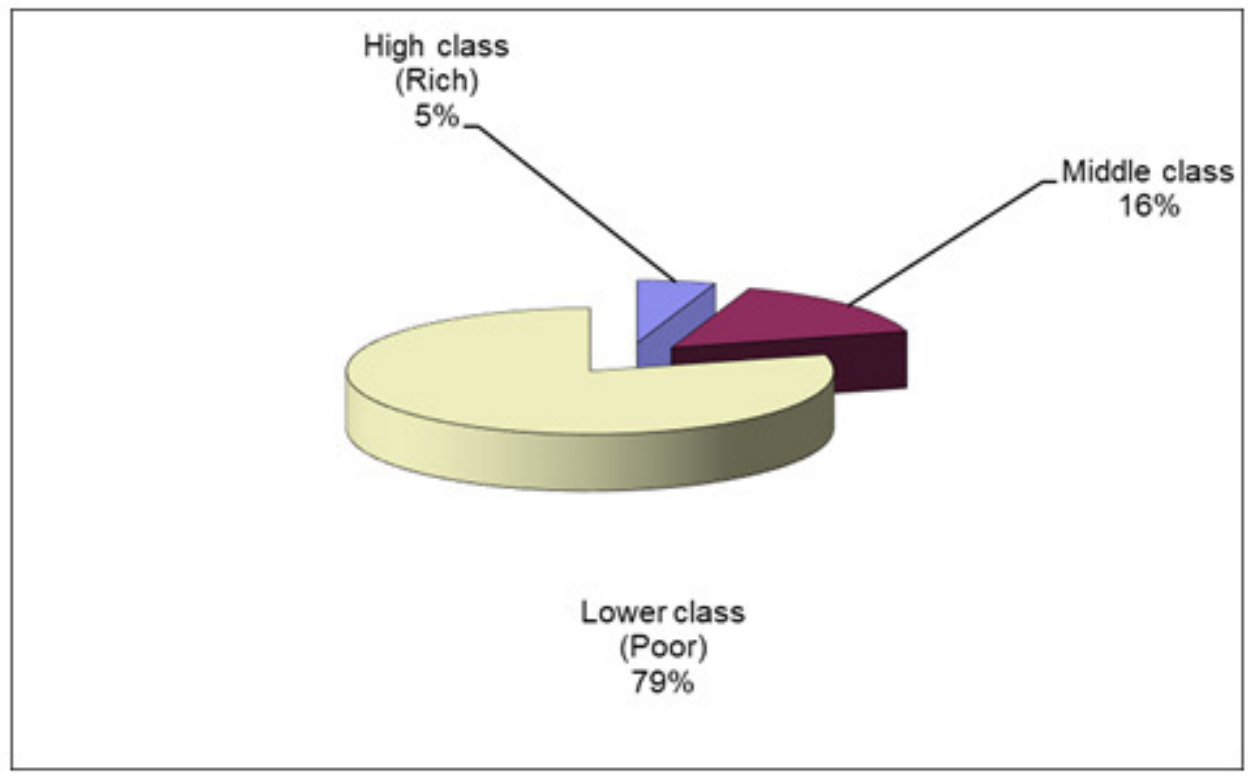

Figure 4: Wealth status/classes of the households in the surveyed villages in Assosa Zone of western Ethiopia 


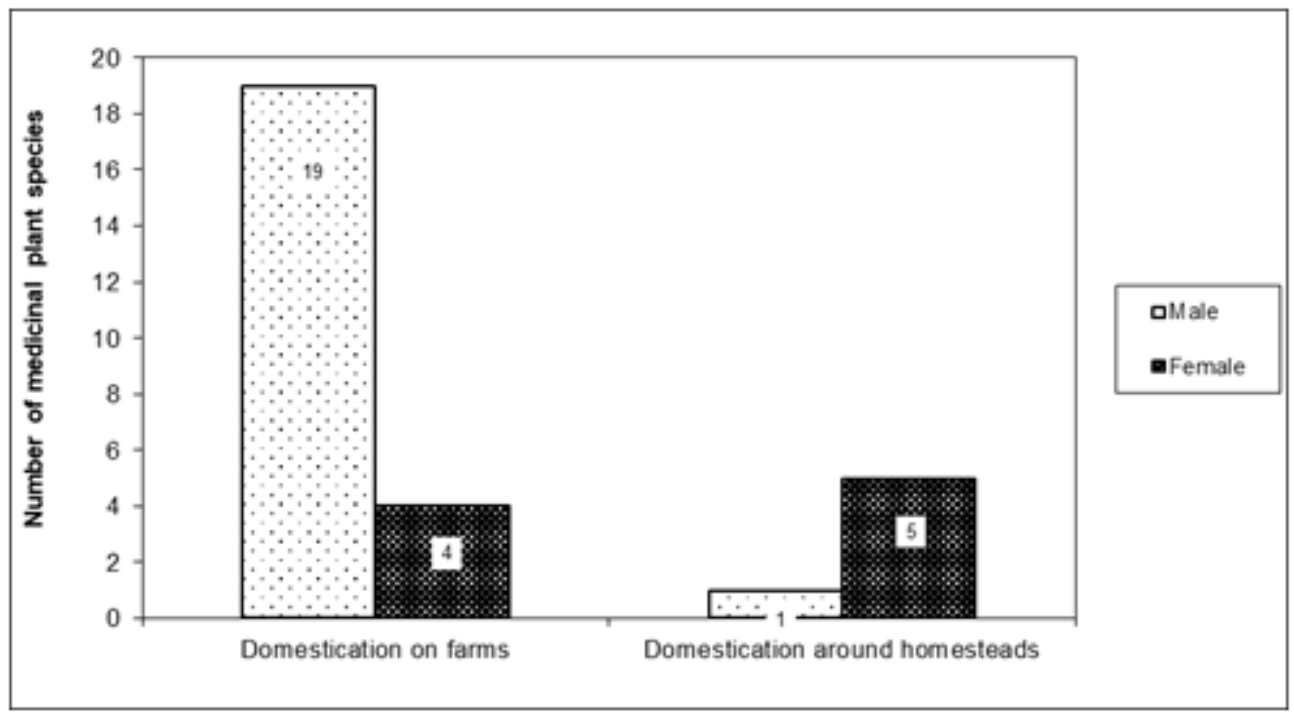

Figure 5: Gender effect on domestication of medicinal plants on farms and around homesteads in the Assosa zoe, Western Ethiopia

The high domestication effort among the wealthy households can be attributed to the cost of maintaining or managing the farms as poor farmers often spend more time looking for food than caring for medicinal plants which they can easily collect from the forests free of charge. Dependence of the poor on natural resources from protected areas is widespread in different parts of the world. In the eastern part of Awash National Park, for example, the households who had fewer or no livestock, constituted the higher proportion of illegal users of resources compared to those who were rich (Loibooki et al. 2002; Kideghesho et al 2005). Sometimes, the poor households supplement their income by working for payment on farms owned by affluent households. This implies that although domestication of medicinal plants can be seen as important coping strategy for poor, economic reasons can impede its adoption.

\section{Education}

From this study, education seems to have had no significant influence on the number of domesticated medicinal plants $\left(P=0.21, R^{2}=26 \%, t=0.27\right)$. The reason for this might be attributed to the fact that virtually all household heads interviewed had formal primary education. The formal education in Ethiopia started orthodox tewahido cherch and thus many respondents had access to this kind of education (Kaoneka, 1993; Kajembe, 1994; Msuya, 1998). Therefore, given the uniformity in education level among the respondents, it is difficult to notice the influence that education can bear on conservation and, domestication in particular. Those educated beyond primary education level, whom we would expect to domesticate more trees due to a relatively high level of awareness, were spending most of their time in towns engaging in business and other activities. Therefore, it wouldn't be surprising if domestication effort would be low for the most educated people as they often spend less time in villages (Kweka 2004).

In areas where the disparity in education level is relatively high, the impact of this factor on participation in or attitude towards conservation is more visible. This is because education can also enhance other factors that can influence conservation efforts or attitudes such as conservation awareness and affluence. For example, an attitude survey on factors influencing conservation attitude in western Serengeti, Tanzania showed that the highly educated people had more income because they had more access to employment opportunities. They were, therefore, more positive and supportive to conservation efforts, because their livelihoods were minimally affected by conservation interventions (Kideghesho et al. 2007).

\section{Family size and sizes of farms}

Other socio-economic factors reported to significantly influence domestication of medicinal plants in the study area were the sizes of the farms $\left(\mathrm{P}=0.023, \mathrm{R}^{2}=45 \%, \mathrm{t}=2.29\right)$ and family size $\left(\mathrm{P}=0.012, \mathrm{R}^{2}=52 \%, \mathrm{t}=2.54\right)$ (Table 2)]. Domestication of medicinal plants was more prominent to households with big farms and big families than those with small. This is likely to be the case because the family size has an implication on the household labour force, and thus big families have more labour, which could contribute positively to the domestication of wild plants including medicinal plants. The studies conducted in South Omo Zone, Ethiopia gave similar results, with big families having planted more trees compared to small ones (Luoga et al., 2004). Other studies have also reported the positive correlation between farm size and domestication of wild plants (Kajembe and Luoga, 1996; Michon and de Foresta, 1996; Moshi, 1997; Ndomba, 2004). A study conducted in the Assosa Zone, revealed 
that the number of plots and farm sizes had a significant and positive influence on tree-growing efforts (Kajembe et al. 2008).

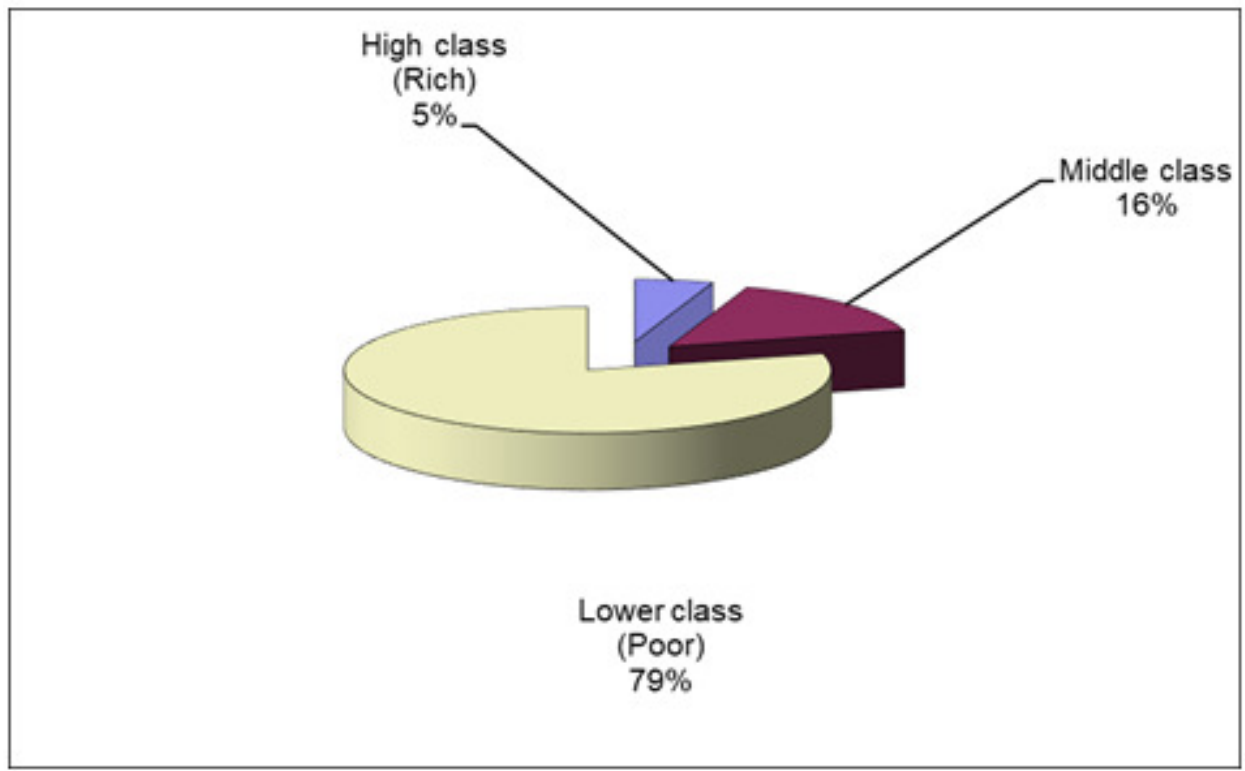

Fig. 5: Wealth status/classes of the households in the surveyed villages in Assosa Zone of western Ethiopia

\section{Ethnicity}

Ethnicity had also influenced domestication of medicinal plants in the study area. The Berta tribe had domesticated more plants $(8 \pm 4(\mathrm{SE})$ than other tribes $(4 \pm 6(\mathrm{SE})$. This practice differed significantly $(\mathrm{P}=0.001$ and $t=5.84)$. This difference could be attributed to the fact that the Berta is the native tribe in the study area and other tribes are immigrants to the Western Ethiopa, and that domestication has been one of the indigenous conservation practice for wild plants in these areas for over 2000 years ago (Hamilton, 1989; Kajembe, 1994; Msuya, 1998; Msuya et al., 2008). Also most of the Berta are traditional healers and hence domestication of medicinal plants was pursued as a way of facilitating their service. Furthermore, traditional healing being a business, motivated domestication of these plants. Most often traditional healing operates on the basis of secrecy (Msuya and Kideghesho 2009). The traditional healers' knowledge on medicine is barely shared with other people. On treating the patients, they never expose the species and their locations. The patients receive the ready made medicines and prescriptions on how to use them. Traditional healers are often considered to be spiritually gifted. Their knowledge can be transmitted to some of their sons or daughters. In some occasions, a person may acquire knowledge on a particular medicinal plant, but he/she has to pay for it. There is a belief that, even if one is familiar with the use and preparation of medicinal species he cannot assume the role of traditional healer, since performance and efficacy of a particular medicine in curing some ailments depends on who dispenses it.

\section{Conclusion and recommendations}

Domestication of medicinal plants is been influenced by gender, socio-economic and cultural factors such as wealth (income), age, farm and household size, and ethnicity. Being part of indigenous agroforestry practice, domestication has played big role in conservation of medicinal plants especially threatened species due to over harvesting and human activities in the Western Ethiopia. It is recommended that more research should be done on medicinal plants to identify other threatened species available in the forests and elsewhere in the study area and come up with appropriate strategies for domesticating them either on farms or around homesteads for sustaining their availability. In the process of domestication; gender, socio-economic and cultural factors with both positive and negative influence, should be taken into consideration.

- Domestication, as a coping strategy, can hardly be implemented by poor communities, who comprise of the majority. Economic empowerment is, therefore, imperative

- Cultural and economic factors are the major factors that impede the ability of women to adopt coping strategies (including domestication) against environmental problems and declining biodiversity. Therefore, the strategies aiming at promoting domestication should aim, among other things, at empowering women economically and intensifying campaigns against discriminatory cultural practices including those denying women access to land and subjecting them to heavy workloads. 


\section{REFERENCES}

Abdallah RK, Hamza KFS, Mwamakimbullah RJL (2007) Use of medicinal plants for maternal care in villages around Zaraninge Forest Reserve in Bagamoyo, Tanzania. Journal of the Tanzania Association of Foresters 11:180-191

Augustino S, Gillah PR (2005) Medicinal plants in urban districts of Tanzania: Plants, gender roles and sustainable use. International Forestry Review 7(1)44-58

Bramwell D (2002). How many plant species are there? Plant Talk 28: 32-34.

Cunningham AB, Mbenkum FT. (1993) Sustainability of Harvesting Prunus africana Bark in Cameroon: a Medicinal Plant in International Trade. People and Plants Working Paper 2. UNESCO, Paris, France

Cunningham AB, Ayuk E, Franzel S, Duguma B, Asanga, C (2002).. An economic evaluation of medicinal tree cultivation: Prunus africana in Cameroon. People and Plants Working Paper 10. UNESCO, Paris, France

Dawson I. (1997) Prunus africana: How agroforestry can help save an endangered medicinal tree ICRAF, Agroforestry Today 9 (2).

De Graaff J (1996) The Price of Soil Erosion: An Economic Evaluation of Soil Conservation and Watershed Development. Wageningen Agricultural University, Wageningen

FAO (1986) Some Medicinal Forest Plants of Africa and Latin America. Forestry Paper No. 67, FAO Rome, Italy

Geraldine M, Prapimporn S, Sompong T (1994) Women in North-eastern Thailand: Preserves of botanical diversity. Indigenous Knowledge and Development Monitor. 2 (3): 24 -24

Green EC (1994) AIDS and STDs in Africa: Bridging the Gap Between Traditional Healing Systems and Modern Medicine. West View Press, Boulder

Govaerts, R., 2001. How many species of seed plants are there? Taxon 50: 1085-1090.

Grünwald, J. \& K. Büttel, 1996. The European phytotherapeutics market. Drugs Made in Germany 39: 6-11.

Hamilton AC (1989) History of resource utilization and management: The pre-colonial period. In: Hamilton AC, and Bensted-Smith R. Editors. Forest Conservation in the Usambara Mountains. IUCN Tropical Forest Programme, Gland and Cambridge

Höft R, Cunningham AB (2002) Primary health care and medicinal plant conservation in Bwindi, South West Uganda. The Newsletter for people and plants 8: 9-11

Ishengoma RC, Gillah PR (2002) The role of medicinal plants in Northern Tanzania. A poster presented during the first Plant Resources of Tropical Africa (PROTA). International workshop $23^{\text {rd }}-25^{\text {th }}$ September 2002, Nairobi, Kenya

Kajembe GC (1994) Indigenous management systems as a basis for community Forestry in Tanzania. A case study of Dodoma urban and Lushoto Districts. Tropical Resource Management Series. No. 6; Wageningen Agricultural University, Norway

Kajembe GC, Luoga EJ (1996) Socio-economic Aspects of Tree Farming in Njombe District. Consultancy Report to HIMA, Njombe conducted by FORCONSULT. Faculty of Forestry, SUA, Morogoro, Tanzania

Kajembe GC, Katani JZ, Lyimo-Macha JG, Nduwamungu J (2008) Coping strategies against deforestation: impact of socio-economic factors with special attention to gender-based indigenous knowledge in the Uluguru Mountains. In: Mukangara F, Shao IF (eds) Gender, Governance and Natural Resources in the Rural Setting: Some Case Studies from Tanzania. The Gender Centre, University of Dar es Salaam; 2008:79-124

Kaoneka ARS (1996) Land Use in the West Usambara Mountains: Analysis of Ecological And Socio-Economic Aspects with Special Reference to Forestry. Unpublished PhD Thesis, Department of Forestry, Agricultural University of Norway

Kaoneka ARS, Solberg B (1997). Analysis of deforestation and economically sustainable farming systems under pressure of population growth and income constraints at the village level in Tanzania. Agriculture Ecosystems and Environment 62 (1): 59-70.

Kerkhof P (1990) Agroforestry in Africa. Panos Institute, London, UK

Kessy JF (1998) Conservation and utilization of natural resources in the East Usambara Forest Reserves: Conservational views and local perspectives. Tropical Resource Management Papers No. 18. Wageningen Agricultural University; 1998

Kideghesho JR (2008). Co-existence between the traditional societies and wildlife in western Serengeti, Tanzania: Its relevancy in the contemporary wildlife conservation efforts. Conservation and Biodiversity 17(8): 1861-1881

Kideghesho JR, Røskaft E, Kaltenborn BP, Mokiti TMC (2005) Serengeti shall not die': Can the ambition be sustained? International Journal of Biodiversity Science and Management, ;3(1):150 -166

Kingazi S, Mombo F, Shemdoe, R (2008) Discovering the hidden values of indigenous tree resources in Shinyanga: A gender perspective in natural resources enterprises: In: Mukangara F, Shao IF (eds) Gender, Governance and Natural Resources in the Rural Setting: Some Case Studies from Tanzania. The Gender 
Centre, University of Dar es Salaam; 125-154

Kweka D (2004). The role of local knowledge and institution in the conservation of forest resources in the East usambara. [Online]. bcb706.blogspot.com/2007/03/potential-role-of-social-taboos-in_482.html - $48 \mathrm{k}$ Accessed on 19 January 2009.

Lashari MS (1984) Traditional and Modern Medicine - is a marriage possible? WHO Forum 5: 175 - 177.

Lange D (1998). Europe's medicinal and aromatic plants. Their use, trade and conservation. - Cambridge, UK, TRAFFIC International.

LeBeau D (1998) Urban patients' utilization of traditional medicine: upholding culture and Tradition. University of Namibia, Sociology Department Windhoek, Namibia

Leaman D (2002). Medicinal plants. Briefing notes on the impacts of domestication/cultivation on conservation. Paper for the "Commercial captive propagation and wild species conservation" workshop, 7-9.12.2001, Jacksonville. (Unpublished report)

Loibooki, M, Hofer H, Campbell KLI, East ML (2002). Bushmeat hunting by communities adjacent to the Serengeti National Park, Tanzania: the importance of livestock ownership and alternative sources of protein and income. Environmental Conservation 29:391-398

Luoga EJ;, Hamza KFS., Kingazi SP; MndolwaM, Msuya TS, Bakengesa S, Maduka S (2004) Socio-economic survey and baseline studies in Ruvu Fuelwood Pilot Project (RFPP) and HASHI/ICRAF Agroforestry Projects. Consultancy Report Submitted to TAFORI, Morogoro, Tanzania

Marshall NT (1998). Searching for a Cure: Conservation of Medicinal Wildlife Resources in East and Southern Africa. TRAFFIC International

Michon G, de Foresta H (1996) Agroforestry as an alternative to pure plantations for the domestication and commercialization of non-timber forest products. International conference on domestication and commercialization of non-timber forest products in agroforestry system $\mathrm{h} t t p: / / w w w . f a o . o r g / d o c u m e n t s / s h o w \_c d r . a s p ?$ url file=/docrep $/ w 3735$ e/w3735e20.

Moshi ERF (1997) Inventory of Indigenous Agroforestry Systems in Practice in the West Usambara Mountains. Unpublished M.Sc. Thesis. The Sokoine University of Agriculture, Morogoro;

Msonthi JD, Seyani JH (1986) The status of research on medicinal plants of Malawi - An overview. Paper presented at the IPS Worksho /Training Course on Pharmacological Screening on Medicinal Plant Products, Zimbabwe

Msuya TS, Kideghesho JR (2009) The Role of Traditional Management Practices in Enhancing Sustainable Use and Conservation of Medicinal Plants in West Usambara Mountains, Tanzania. Tropical Conservation Science2(1):88-105

Msuya TS (1998) Uses and Indigenous Conservation Methods of Wild Plants: A Case of West Usambara Mountains, Tanzania. Unpublished M.Sc. Thesis. NORAGRIC, Agricultural University of Norway

Msuya, TS (2002) Women and Plant Biodiversity Conservation. TAFORI Newsletter 2(2):17-18.

Msuya TS, Mndolwa MA, Kapinga C (2008) Domestication: an indigenous method in conserving plant diversity on farmlands in west Usambara Mountains, Tanzania. African. Journal of. Ecology 46 (Suppl. 1): 74 - 78

Ndomba CJ (2004) A Socio-Economic and Ecological Evalution of Ruvu Fuelwood Pilot Project (RFPP) in Kibaha, Tanzania. M.Sc. Thesis in the Management of Natural Resources and Sustainable Agriculture. Sokoine University of Agriculture, Morogoro, Tanzania

Otieno NJ (2000) Biomass, Inventory and Potential of Indigenous Medicinal Plants: A Case Study of DuruHaitemba Community Forest, Babati District, Tanzania. Unpublished M.Sc. Thesis, Sokoine University of Agriculture, Morogoro, Tanzania

Quiroz C (1994). Biodiversity, indigenous knowledge, gender and intellectual property rights. Indigenous Knowledge and Development Monitor 2: 12-14.

Rukangira E (2001). The African herbal industry: Constraints and challenges. Conserve Africa International. Paper presented at "The natural Products and Cosmeceuticals 2001 conference".

Rulangaranga ZK (1989) Some Important Indigenoue Medicinal and Aromatic Plants in the Wild Flora of Tanzania Mainland. Ministry Of Lands, Natural Resources And Tourism, Forest And Beekeeping Division. Tropical Forestry Action Plan Working Paper No. 24, Dar es Salaam, Tanzania

Schippmann U, Leaman D, Cunningham AB (2006) A comparison of cultivation and wild collection of medicinal and aromatic plants under sustainability aspects. p. 75-95. In: Bogers RJ, Craker LE, and Lange D (eds.) Medicnal and aromatic plants. Proc. Frontis Workshop on Medicnal and Aromatic Plants. Wageningen, The Netherlands, 17-20, April 2005. Nucleus for Strategic Expertise Wageningen University and Research Centre, Wageningen.

Songorwa, A.N., T. Buhrs, and K.F.D. Hughey. 2000. Community-based wildlife management in Africa: A critical assessment of the literature. Natural Resources Journal 40:603-43.

Talhouk SN, Lorbach I, Karmann M (2001) Gender knowledge about non-timber Forest products. European Tropical Forest Research Network (ETFRN) Newsletter, 2001;32: 27-29. 
URT (United Republic of Tanzania) (2003). 2002 National Population and Housing Census: General Report. The United Republic of Tanzania, Government Printer, Dar es Salaam, Tanzania

Walter KS. and Gillett HJ (1998). 1997 IUCN Red List of threatened plants. - Gland, Switzerland, IUCN.

WCMC (World Conservation Monitoring Centre) (1992) Global Biodiversity: Status of the Earth's Living Resources. Chapman and Hall, London; 1992

Wiersum KF, Anspach CL, Boerboom JHA, Rouw A, Veer CP (1985) Development of ecological methods of upland farming in West Usambara Mountains, Tanzania. FAO Forestry Paper 5:55 - 82

World Bank (1993) World Development Report: Investing in Health. Oxford University Press, New York 